\title{
Epidemiology of Tularemia
}

\author{
Şaban Gürcan
}

Department of Medical Microbiology, Trakya University Faculty of Medicine, Edirne, Turkey

Tularemia is considered to have existed in Anatolia for several thousand years. There are suspicions regarding its use in biological warfare in the Neshite-Arzawan conflict. The causative agent of tularemia may have first been used as a biological weapon in 1320-1318 BC. The disease has recently become a significant re-emerging disease globally as well as in Turkey. In the period of 2001-2010, Kosovo had the highest annual incidence in Europe at a rate of 5.2 per 100,000. Sweden, Finland, Slovakia, Czech Republic, Norway, Serbia-Montenegro, Hungary, Bulgaria, and Croatia follow with rates of 2.80, $1.19,1.0,0.81,0.42,0.4,0.36,0.21$, and 0.15 per 100,000 people, respectively. Tularemia in Turkey was first reported in the soldiers living in the region very close to the Kaynarca Stream of Thrace in 1936. It has started to gain more and more importance, especially in recent decades in Turkey, due to a very high number of cases and its spread throughout the country. A total of 431 tularemia cases were recorded in Turkey in 2005, but a significant reduction was observed in the number of the cases in the next three years; the number of patients decreased to $71 \mathrm{in} 2008$. The number of cases increased again in 2009 and continued in subsequent years. The number of cases reached 428 , 1531,2151 , and 607 in 2009, 2010, 2011, and 2012, respectively. The number of cases peaked in 2011 in Turkey, and was in fact higher than the total number of cases in all European Union countries. The number of cases is higher in females than males in Turkey. In Turkey, $52 \%$ of cases of tularemia diagnoses occur from December to March and the most common clinical presentation is the oropharyngeal form caused by contaminated water. Rodents are the most likely sources of tularemia outbreaks in Turkey as well as in Kosovo. Organisms such as ticks, flies and mosquitoes are vectors of tularemia transmission to mammals. Because ticks can carry the bacteria by both transovarial and transstadial transmission, they play a role in the life cycle of tularemia as both reservoir and vector.

(Balkan Med J 2014;31:3-10).

Key Words: Epidemiology, Francisella tularensis, tickborne disease, tularemia, water-borne disease
Also known as "rabbit fever", "hunters' disease", "deerfly fever", "tick fever", "O'Hara's Disease" and "Francis' Disease", tularemia is a common zoonotic disease in Turkey and throughout the world. The disease has started to gain more and more importance, especially in recent decades in Turkey due to a very high number of the cases and spread throughout the country $(1,2)$. Tularemia has recently become a significant re-emerging disease in the world because of the important role of bacteria in biological terrorism agents. Bioterrorism using anthrax has occurred in the United States, and an increase in tularemia cases has been the result of global warming, wars, natural disasters, human travel and animal movements (3-6). This review will focus on the epidemiological features of tularemia throughout the world and Turkey.

\section{HISTORY}

Tularemia was first been reported in Turkey in 1936, but it is considered to have existed in Anatolia for several thousand years (7-10). The presence of a disease, possibly tularemia, has been known in Central Anatolia since the $14^{\text {th }}$ century BC, during the
Hittite period. It is believed that this disease arrived by means of wars, travel, ticks or rodents to Anatolia from the Middle East region. Many people, including rulers and aristocrats, died from the disease in Syria, Egypt and Lebanon. It has led to social unrest, especially in Egypt (8-10). There are suspicions regarding the use of causative agent of tularemia as biological warfare in the Neshite-Arzawan conflict in 1320-1318 BC. It is thought that the Neshites may have won the conflict by sending diseased rams to the Arzawans, thereby weakening their military force. The source of the term "Hittite Plague" term may refer to this biological warfare event. There are many papyri belonging to this period in Hittite and Egyptian inscriptions $(9,10)$.

Tularemia is mainly reported worldwide in the northern hemisphere $(2,5)$. Many people have died from this disease in the Middle East, especially in the 1400s BC (10). Tularemia was first described as a disease of the rodent group called lemmings in the $16^{\text {th }}$ century in Norway. It was also described in Japan and Russia in the 1800s $(11,12)$. The infectious agent was isolated by MacCoy and Chapin from dead ground squirrels in 1911 in Tulare, California, USA after the San Francisco earthquake in 1906. During this period, the bacteria had been referred to as Bacterium tularense to recognize the region 
of its discovery (5). The first human cases were reported by Lamb and Wherry in 1914 (12). Edward Francis was the first person who studied the epidemiology of the disease in humans, and described the clinical manifestations in humans. He stated that many people with different clinical presentations suffered from the same disease, and initially used the term "tularemia" for the disease. It was found to be transmitted through contact with the infected meat of rabbits and rodents. Serological tests were devised for the diagnosis, and a vector role of blood-sucking flies was established $(11,13,14)$.

Bacterium tularense was initially included into the genera Brucella and Pasteurella, but was then designated as a new genus for its taxonomy in 1947. The genus, Francisella, was named in honor of Edward Francis, who contributed greatly to tularemia research. The species, tularensis, is named for Tulare County where tularemia was first observed. Another species, F. philomiragia, was placed in the genus Yersinia in 1959. Afterwards, it was included in the Francisella genus. This species is less virulent than $F$. tularensis (15). Another species, $F$. noatunensis, was isolated from Atlantic cod ( $\mathrm{Ga}$ dus morhua L.) as F. philomiragia subsp. noatunensis in 2007 $(16,17)$. It was later added to genus Francisella as a species of this genus (18). Recently, three additional species, i.e. $p i-$ scidida, hispaniensis, and guangzhouensis, were also added to genus Francisella $(19,20)$. Therefore, six species are placed in the Francisella genus, including $F$. tularensis, F. philomiragia, F. piscidida, F. noatunensis, F. hispaniensis and F. guangzhouensis (21). Nowadays, F. tularensis is classified as four subspecies consisting of $F$. tularensis subsp. tularensis (Type A), F. tularensis subsp. holarctica (Type B), F. tularensis subsp. mediasiatica, F. tularensis subsp. novicida (5).

\section{TRANSMISSION}

Tularemia is more common in some groups of people. Groups at risk include foresters, hikers, hunters, people in contact with meat and animals, people living in rural areas, farmers, laboratory workers and veterinarians $(2,5,22)$.

In humans, the clinical symptoms of tularemia may vary depending on the bacterium's virulence, amount, mode of entry into the body, and the person's immunity. Tularemia may be detected as only seropositive cases with no symptoms at all, or may lead to sepsis and death with quite different clinical findings (23-25). The rate of asymptomatic tularemia varies between $4-19 \%$ (14). So far, only one patient has died from tularemia in Turkey; this occurred in the Thrace region in 1936 (26).

The number of cases is higher (1.18 times) in females than males in Turkey (14). However, outside of Turkey, the number of cases is higher in males than females (27). The reason for higher female prevalence in Turkey may be due to the fact that women may be more active in household chores, and have more contact with contaminated water and with animal excrement or urine in food storage areas (14). Other reason for the different sex distribution may also be the fact that the oropharyngeal form of tularemia is more common in Turkey than in other countries; it is caused by the consumption of contaminated water or food. In contrast, the ulceroglandular form is the most common type of tularemia in other countries; it is caused by blood-sucking insects or arthropods (28). In the period of 2005-2009 in Turkey, $99 \%$ of 1091 cases were the oropharyngeal form of tularemia. According to the age of these cases, $19.3 \%$ of the patients were less than 20 years old. Most patients (53.8\%) were in the age group of 30-64 years. This suggests that the disease usually affects adults. The average age is reported to be 38.7 years for women and 30.6 years for men (14).

The oropharyngeal form of tularemia is common in regions dominating aquatic cycle and is caused by the consumption of contaminated water or food. Urine, excrement or other excretions of animals involved in the aquatic cycle such as beaver, muskrat and voles can contain the causative agent and infect surface waters after rainfall in the winter months. The main reason for the oropharyngeal form is the consumption of contaminated water by people (28). In Turkey, $52 \%$ of tularemia diagnoses occur from December to March (Table 1) (2949). Due to these reasons, the aquatic cycle appears to be the main ecological cycle for tularemia in Turkey. The emergence of tularemia cases (of 1441 patients, 91.5\%) in Turkey usually starts in August and lasts until March.

Tularemia can exist in nature for long periods of time. It affects more than 100 mammals, birds, cold-blooded animals and arthropods (5). F. tularensis infects rabbits, mice, squirrels, beavers, rats, weasels, foxes, mink, sheep, cats, dogs, horses, pigs, many other wild mammals, more than 25 species of fowl, fish species, and many cold-blooded animals. Rodents (Rodentia; mice, rats, and squirrels) and hares (Lagomorphia) are the most important reservoirs for tularemia, according to epidemiological data obtained from various studies. Rodents are separated into two parts as terrestrial and aquatic rodents. However, all rodents are reservoirs in nature and take part in the life cycle of tularemia. Circulation continues among these animals in tularemia endemic areas. Although people and pets are not the main hosts, they are involved in these cycles as well. Throughout history, there have been noteworthy relationships between common animal deaths and outbreaks of tularemia in humans. A positive correlation is usually found in the relationship between the numbers of human cases and the numbers of animals infected with $F$. tularensis $(39,44,50)$. High numbers of infected rodents such as mice, hares, and ground squirrels have resulted in an increase in the number of tularemia cases in humans in the Nordic countries and Russia $(2,5,50)$.

The persistence of $F$. tularensis is considered to be divided into two cycles, i.e. the terrestrial and aquatic cycles $(14,22)$. Small rodents, hares, and arthropods (Dermacentor, Amblyomma, Haemaphysalis and Ixodes spp.) are very important in the terrestrial cycle of $F$. tularensis. Tularemia is usually fatal in these animals. The infectious dose of $F$. tularensis is very 
TABLE 1. Monthly distribution of the tularemia cases in Turkey according to published literature

\begin{tabular}{|c|c|c|c|c|c|c|c|c|c|c|c|c|c|c|c|}
\hline \multirow[t]{2}{*}{ Regions } & \multirow[t]{2}{*}{ Years } & \multirow{2}{*}{$\begin{array}{l}\text { Total number } \\
\text { of the cases }\end{array}$} & \multicolumn{13}{|c|}{ Months } \\
\hline & & & December & January & February & March & April & May & June & July & August & September & October & November & References \\
\hline Kurklareli-Tekirdağ & 1936 & 133 & & & & & & & 3 & 47 & 77 & 6 & & & 29 \\
\hline Bingöl-Tatvan-Reşadiye & 1937 & 6 & & & & & & & & & 6 & & & & 30 \\
\hline Kırklareli-Lüleburgaz & 1945 & 15 & & & & & & & 2 & 5 & 7 & 1 & & & 31 \\
\hline Antalya-Bademağacı & 1953 & 200 & & & & & & & & & 100 & 100 & & & 32 \\
\hline Bursa & $1988-1998$ & 205 & & Winter & & & & & & & & & Autumn & & 23 \\
\hline $\begin{array}{l}\text { Ankara-Ayaş- } \\
\text { Yağmurdede }\end{array}$ & 1997 & 16 & 16 & & & & & & & & & & & & 33 \\
\hline Düzce-Akçakoca & 2000 and 2005 & 33 & & & 11 & & 22 & & & & & & & & 34 \\
\hline Bolu-Gerede-Yazıkara & 2001 & 21 & & & & & & & & & & 21 & & & 25 \\
\hline Amasya-Suluova & 2004 & 86 & & & & & & & & & & & 86 & & 35 \\
\hline $\begin{array}{l}\text { Zonguldak- } \\
\text { Kastamonu-Bartın }\end{array}$ & & 2004-2005 & 61 & & 61 & & & & & & & & & & 36 \\
\hline Kars-Sarıkamış & 2004-2005 & 56 & & & 49 & & & & & & & 7 & & & 37 \\
\hline Kocaeli-Gölcük & 2004-2005 & 145 & & 145 & & & & & & & & & & & 38 \\
\hline $\begin{array}{l}\text { Kocaeli-Karamürsel- } \\
\text { Pazarköy }\end{array}$ & 2005 & 17 & & & 17 & & & & & & & & & & 39 \\
\hline $\begin{array}{l}\text { Edirne-Lalapaşa- } \\
\text { Demirköy }\end{array}$ & 2005 & 10 & & & 10 & & & & & & & & & & 24 \\
\hline Samsun-Havza & $2005-2007$ & 75 & 14 & 25 & 14 & 6 & 1 & & & & 1 & & 2 & 12 & 40 \\
\hline Sakarya-Kocadöngel & $2005-2006$ & 63 & & & 63 & & & & & & & & & & 41 \\
\hline Bolu-Gerede-Nuhören & 2006 & 6 & & 6 & & & & & & & & & & & 42 \\
\hline Tokat 2 & 2005 and 2010 & 23 & 8 & & & & & 15 & & & & & & & 43,44 \\
\hline Sivas & 2008-2010 & 29 & 6 & 12 & 6 & 2 & & & & & & & & 3 & 45 \\
\hline Çanakkale & 2009 & 36 & 36 & & & & & & & & & & & & 46 \\
\hline Çankırı-Çerkeş-Kadıözü & 2009 & 18 & 16 & & & & & & & & & & & 2 & 47 \\
\hline $\begin{array}{l}\text { Tekirdağ-Hayrabolu- } \\
\text { Muzruplu }\end{array}$ & 2010 & 8 & & & & & & & & & & 8 & & & 28 \\
\hline Konya & 2009-2010 & 40 & 21 & & & & & & & & & & & 19 & 48 \\
\hline Central Anatolia & 2009-2011 & 139 & 23 & 23 & 38 & 29 & 10 & 1 & 3 & 3 & 7 & & 2 & & 49 \\
\hline Total number* & 1936-2011 & 1441 & $\begin{array}{c}210 \\
(14.6)\end{array}$ & $\begin{array}{c}176 \\
(12.2)\end{array}$ & $\begin{array}{l}249 \\
(17.3)\end{array}$ & $\begin{array}{r}115 \\
(8)\end{array}$ & $\begin{array}{c}32 \\
(2.2)\end{array}$ & $\begin{array}{l}22 \\
(1.5)\end{array}$ & $\begin{array}{l}13 \\
(0.9)\end{array}$ & $\begin{array}{c}55 \\
(3.8)\end{array}$ & $\begin{array}{c}198 \\
(13.7)\end{array}$ & $\begin{array}{l}177 \\
(12.3)\end{array}$ & $\begin{array}{l}124 \\
(8.6)\end{array}$ & $\begin{array}{c}70 \\
(4.9)\end{array}$ & \\
\hline
\end{tabular}

*Numbers belonging to more than one month were equally distributed to each of these months

low, i.e. $10^{2}$ colony forming unit (CFU)/mL to $10^{3} \mathrm{CFU} / \mathrm{mL}$. The spleen of a mouse that died from tularemia contains $10^{10}$ CFU bacteria (51). Another study (52) showed that the bacteremic dose is greater than $10^{8} \mathrm{CFU} / \mathrm{mL}$ in the blood and the lethal dose of bacteria is $10^{9}-10^{10} \mathrm{CFU} /$ organ in the spleen, liver and lung of mice. However, some rodents can survive without clear symptoms of the disease. Bacteria can also be transferred to other rodents from asymptomatic rodents by blood-sucking arthropods such as ticks, flies, and mosquitoes, or they may persist in the environment.

Ticks are very important in the persistence of infection as they ensure the permanence of these bacteria in nature. Ticks infect the circulatory system of the host by their feces or bites. Bacteria are transmitted to wild animals or domestic animals (sheep, cattle, goats, horses, pigs, dogs, and cats) by ticks and blood-sucking flies (mechanical vectors). Some ticks can carry bacteria in their bodies for a lifetime (reservoir). Tick-borne tularemia infection in humans usually occurs in the summer months when ticks are more active. F. tularensis can survive up to two weeks in insects. Horse flies and deerflies in the United States and mosquitoes in Northern Eurasia are important in the transmission of the bacteria. In the natural cycle of F. tularensis subsp. holarctica, rodents associated with water (beavers, muskrats and other types of rats, ground and water voles, wild rabbits, squirrels and raccoons) play a major role as reservoirs $(2,14,22,50,53)$.

The reservoir of $F$. tularensis varies from country to country. The most common reservoirs are Arvicola terrestris (water vole) and Microtus arvalis (field vole) as well as Rattus rattus (black rat) in Europe, Arvicola terrestris, Mus musculus, and hares in the Lepus genus in Russia, and hares in the Sylvagus genus in North America (50). In a study in Bulgaria, among 169 rodents caught in the wild, 37 of them were found to be infected with $F$. tularensis using molecular tests. Of these infected rodents, 32 and 5 were Rattus rattus and Mus musculus, respectively. F. tularensis could not be demonstrated in 9 Apodemus agrarius (54). However, two A. agrarius were shown to be infected by F. tularensis in a study of 64 rodents 
caught in Kosovo (55). When the carcass, meat, excrement, or urine of these animals contaminate food or water, tularemia results from the consumption of contaminated water or food. An increase in the rodent population such as voles is remarkable in epidemic periods of winter in Europe. It is not known exactly how hares interact with the microorganism, but it is thought that they are affected by the residues of mice on grasses and plants $(50,56)$.

There have been very few studies on the animals that carry tularemia in Turkey. Some authors (24) investigated the disease in sheep, cattle, mice, and rabbits during an outbreak that occurred in 2005 in the Thrace region (Edirne-Demirköy). They identified antibodies against $F$. tularensis at low titers ranging from $1 / 20$ to $1 / 80$ in one of 25 rabbits, in 19 of 27 cattle but in none of 19 sheep. F. tularensis was not isolated on the suspension of the three ticks on animals and none of the liver and spleen tissues of eight Rattus rattus and a dead rabbit in the village. The other authors (57) failed to find a causative agent by culture and molecular methods in the liver and spleen of 42 Microtus socialis collected from epidemic regions of central Anatolia.

Rodents are the animals suspected as the most likely sources of the tularemia outbreaks in Turkey and Kosovo in 1999 and 2000. A large number of water voles and other rodents were found dead in Lüleburgaz and Kurklareli in Turkey between the 1930 and 1945. In a survey conducted by Dr. Talat Vasfi Öz (26) in the region during this period, approximately 150 cases were diagnosed as tularemia in 28 villages and the district of Kırklareli as well as six villages in Tekirdağ. A strong relationship between mice and tularemia was obtained according to his observations. For example, Dr. Öz (26) described that when mice gnawed melons in a villager's house in Kırıkköy of Kurklareli, the household did not want to eat the melons for this reason. Nevertheless, the father ate the fruit and developed fever and swelling of his neck in a few days; he then suffered from the disease for several months. The stories of the villagers were interesting in terms of the important role between dead mice, contamination with their waste and tularemia. The villagers living in Hamzabey did not believe that their water was infected by the causative agent. A villager and his children drank water from the stream. After 2-3 days, they were seriously ill, their lymph nodes were swollen, and their body temperatures had increased (26). Rice cultivation, which needs a lot of water, was banned in the region following these observations, and it significantly reduced the number of rodents. Consequently, termination of the tularemia outbreak was achieved. After this period, an outbreak was seen in 1945 in Lüleburgaz, in the district of Kurklareli. Tularemia was eradicated, or at least was not diagnosed for a very long time after 1945 (5). It was observed that the number of mice remarkably increased in the year prior to outbreaks that occurred in 1998 (BursaKaracabey), in 2005 (Edirne-Demirköy), in 2010 (Kırşehir), and some other outbreaks $(24,57,58)$. A relationship between tularemia in mice and human cases was suspected in Turkey, but this thesis could not be confirmed until recently $(24,57$, 59). Recently, the causative agent of tularemia was found in mice collected from villages of the Thrace region where tularemia had been reported (60). In the mentioned study (60), its presence was demonstrated using molecular methods on two mice captured from Kaynarca village, which was considered to be the main focus of the outbreak in 1936. Thus, it was shown that the causative agent of tularemia was carried by voles and their potential role in tularemia transmission was confirmed in Turkey for the first time (60).

F. tularensis is highly resistant to external environmental conditions. Especially amoebae living in water (Acanthamoeba Castellani) are important for the bacteria that survive in nature $(50,61)$. Bacteria can survive for years in water, soil, mud, swamps, animal wastes, barns, and frozen meats $(6,11,12,14)$.

Humans are one host for F. tularensis, as well as many species of birds, fish and reptiles $(2,62)$. Although some data are missing in birds, it is thought that they play a role in the spread of the agent worldwide $(63,64)$. Birds, rodents, and hares can carry the same ticks in some regions. For this reason, they are thought to contribute to the persistence of $F$. tularensis in nature (50).

Organisms such as ticks, flies and mosquitoes are responsible for the transmission of tularemia to mammals. This transmission is possible among wild animals, pets, and humans. Because ticks can carry the bacteria by both of transovarial and transstadial transmission, they play a role in the cycle of tularemia as both a reservoir and a vector. While Ixodes ricinus and Dermacentor reticularis ticks are the main sources of tularemia in Europe, and they play a central role in most regions of America, flies are more common vectors in other regions. Amblyoma, Dermocentor, and Ixodes species are responsible for transmission. Crysops (deer flies), which belong to the family Tabanidae, and Tabanus (horse flies) can mechanically infect animals with their mouth organs. These flies carry F. tularensis in the western United States and Russia, and most of the tabanid flies can be infected with F. tularensis (65). Transmission is also possible by Aedes, Culex or Anopheles mosquitoes and Ixodes, Dermocentor or Rhipicephalus ticks (50). Most of the cases in the Nordic countries are caused by the bite of mosquitoes. Mosquito-transmitted tularemia cases are more often diagnosed during the summer months, unlike water-borne tularemia. Some mosquitoes are infected in the natural environment, but they carry only the mechanically causative agent because there are no bacteria in their salivary glands. Aedes cinereus mosquitoes are a naturally infected form, first reported in Sweden (66). Edward Francis reported that Cimex lectularis (bedbugs) is important for tularemia transmission. In subsequent years, it was seen that bedbugs could play a role in the transmission of tularemia in most cases as a vector. Water-borne oropharyngeal tularemia is a common form, and tick-borne tularemia is rarely reported in Turkey. Two tularemia cases were reported in Yozgat in 2011 after tick bites (67). There was also a suspicion of tick exposure in three cases reported in Düzce in 2000 (68). Transmission by mosquitos or other flies has not 
been accurately described in Turkey. However, it is thought that some soldiers could have been infected by insects at the Lüleburgaz Military Facility during the Kaynarca outbreak that occurred in 1936 (26).

Miller (69) was the first researcher to describe water-borne tularemia. Dr. Tahsin Berkin and Dr. Talat Vasfi Öz (26) concluded that tularemia was mostly a water-borne disease in the Thrace outbreaks between 1936 and 1937. It was thought that the Kaynarca River, with a military garrison nearby, was the main source of the disease. This thesis was supported by the anamnesis of the soldiers who had bathed in the stream and then had suffered from the disease, as well as the existence of the disease in the villages near the stream and among rice field workers and some villagers that had bathed in the stream. Unfortunately, studies on both water samples and samples of animals such as rabbits and ticks collected from the local environment failed to confirm the contamination. Therefore, how animals contaminated the water and which animals were contaminated with bacteria was not exactly demonstrated $(26,29)$.

\section{REPORTED TULAREMIA CASES AND FREQUENCY}

Tularemia has been reported in many regions of the world since its original description in the United States. There have been many tularemia cases in parts of North America, central Asia, Russia, the Nordic countries, the Balkans, and Japan $(1,22)$. Especially North America and the Nordic countries are endemic areas for tularemia. Outbreaks also occur in Eastern Europe and Russia. The incidence of tularemia is 0.5 to $5 /$ one million cases per year in the United States. A major outbreak occurred in 1939 that affected 2,291 people in the United States. While the annual number of cases was about 900 in the United States in 1950, it gradually decreased in subsequent years, and the number of the cases was approximately 100 patients in $2010(70,71)$. A tularemia outbreak affected more than 100,000 people in the Soviet Union in 1940 (70). In 1950, a large outbreak occurred in Germany and a large number of cases were reported in countries such as the Czech Republic, France, Sweden and Finland. The prevalence of tularemia increased after the Second World War, especially in Eastern European countries and Russia. The rise in the number of the cases was especially remarkable in the Balkan countries in recent decades compared with the incidence of tularemia throughout the world $(14,22,70,71)$. Outbreaks occurred in 1999-2000 because of the negative effects of the war in Kosovo. In the following years, the outbreak continued there, and the number of cases reached 1,221 between 1999 and 2010. In the period 2001-2010, Kosovo had the highest annual incidence of tularemia in Europe at a rate of 5.2 per 100,000 (71). Sweden, Finland, Slovakia, Czech Republic, Norway, Serbia-Montenegro, Hungary, Bulgaria, and Croatia followed with rates of 2.80, $1.19,1.0,0.81,0.42,0.4,0.36,0.21$, and 0.15 per 100,000 people, respectively (72). Interestingly, tularemia has not been reported in the United Kingdom, Iceland, Africa, South America and Antarctica. To date, Australia has had only two tularemia cases related to $F$. tularensis $(73,74)$.

Tularemia in Turkey was first reported in soldiers living in the region very close to the Kaynarca stream in Thrace in 1936. The majority of these cases were soldiers who had a history of bathing in the Kaynarca stream and were admitted to the Lüleburgaz Military Hospital. Another small group included the villagers living in the same region and using the same water source $(7,29)$. A second tularemia outbreak was occurred in Lüleburgaz nine years later (31). These outbreaks affected 168 people in total (26). Additionally, some cases were reported in several places in Turkey (some parts of eastern Anatolia, Tatvan, and Konya). Six patients were affected in the Tatvan-Reşadiye outbreak (30).

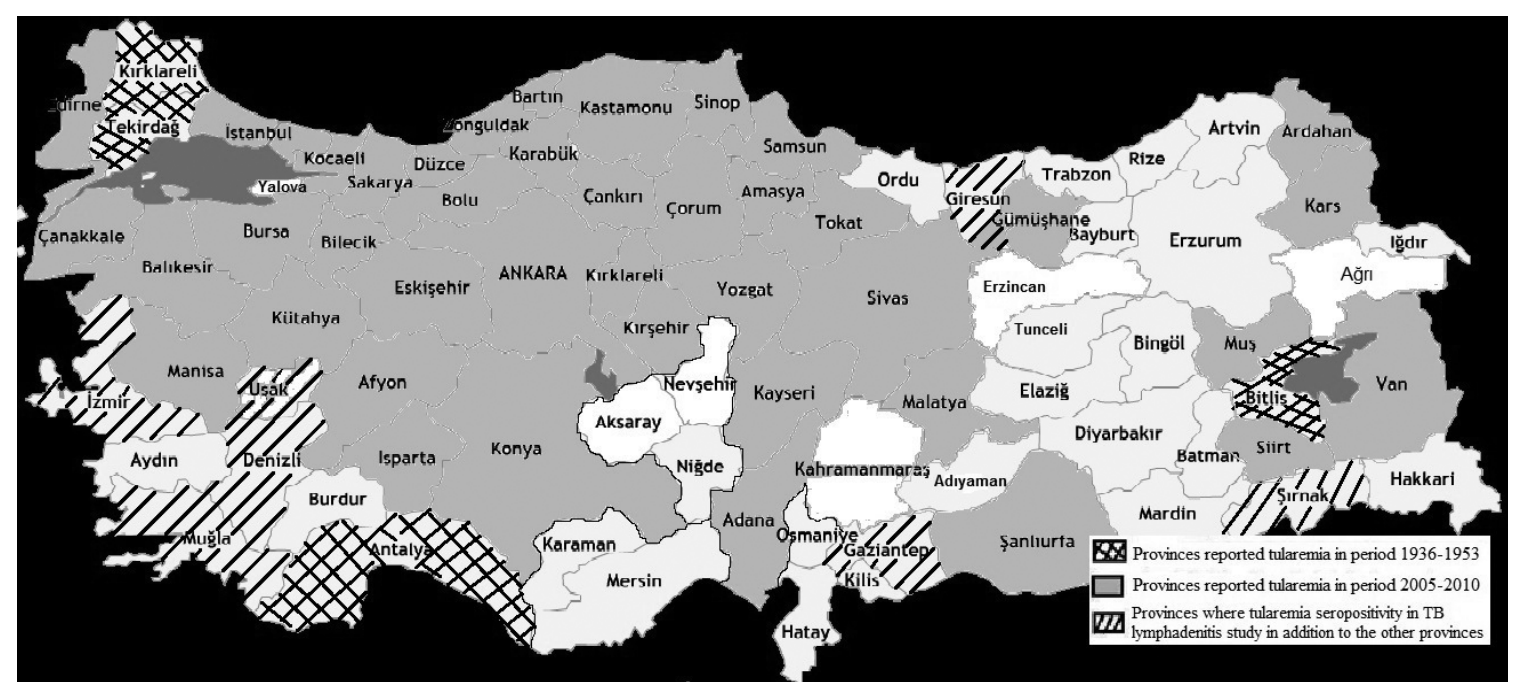

FIG. 1. Distribution of tularemia in the cities of Turkey (72) 
In 1953, Turkey's biggest tularemia outbreak was reported. According to the researcher Ibrahim Ethem Utku, about 300 (at least 200) people or 154 patients (according to hospital records) suffered from the outbreak which occurred in Bademağacı village, $57 \mathrm{~km}$ north of Antalya (32).

Tularemia had a quiet period between 1953 and 1988 in Turkey. Then, it emerged in new outbreaks in many villages of Bursa-Karacabey in 1988 (58). In the research performed on this outbreak, an increase in the number of mice was observed in the villages at the time of the epidemic period, and water was suspected as the source of the outbreak (75). Sporadic cases or small outbreaks continue to be reported from Bursa to date (23). A total 372 patients were diagnosed with tularemia in the Bursa region between 1988 and 2004. Another outbreak affecting 70 people was also reported in Bursa, i.e. in Yörükali village, in $2005(76,77)$.

Tularemia outbreak reports have increased in recent decades in Turkey. These reports are as follows: 16 cases in Ankara Ayaş Yağmurdede (1997); 35 cases in Bilecik Pazarcık Ahmetler (1998); 49 cases in Samsun (1999 and 2001); 40 cases in Sinop (2000); 22 cases in Yalova (2000); 33 cases in Düzce (2000 and 2005); 30 cases in Bolu Gerede (20012006); 126 cases in Balıkesir (2002); 129 cases in Amasya Suluova (2004); 61 cases in Zonguldak, Kastamonu and Bartın of Western Black Sea Region (2004-2005); 56 cases in Kars (2004-2005); 162 cases in Kocaeli (2004-2005); 10 cases in Edirne Lalapaşa Demirköy (2005); 75 cases in SamsunHavza (2005-2007); 63 cases in Sakarya (2005 and 2006); 23 cases in Tokat (2005 and 2010); 20 cases in Çankırı Çerkeş Kadıözü (2009); 36 cases in Çanakkale (2009); 29 cases in Sivas (2009-2010); 8 cases in Tekirdağ Hayrabolu Muzruplu (2010) and 40 cases in Konya (2010) (14, 24, 25, 28, 33-37, 40, 42-46, 48, 49, 78).

After the period when outbreaks were reported all over the country in 2009, cases (more than 500) were mostly reported from the central Anatolia region, especially from Yoz- gat (49). If it was considered that the disease in some patients was misdiagnosed and not included in the statistics, the number of the cases would be much higher in Turkey. In fact, very interesting results were obtained in a comprehensive study on tuberculosis which was confused with tularemia. In this study, the sera of the patients with a diagnosis of tuberculous lymphadenitis in the Tuberculosis Dispensaries of Turkey were investigated for tularemia antibodies. It was shown that a significant proportion of these cases could be tularemia. Seropositivity was found even in areas never having reported tularemia (Figure 1) (79).

Because reliable data cannot be obtained about tularemia, it was included in the list of "The Notification System of Communicable Diseases (Group C)" by the Turkish Health Ministry in $2005(5,14)$. In this way, more reliable epidemiological data were obtained after 2005. A total of 431 tularemia cases in Turkey were noted in 2005, and a significant reduction was observed in the number of the cases in the next three years, as the number of patients decreased to 71 in 2008 . The number of cases again increased in 2009 and continued in the following years. The number of cases was 428, 1531, 2151, and 607 in $2009,2010,2011$, and 2012 respectively $(14,72,80)$. The number of the cases peaked in 2011 in Turkey, and was higher than the total number of cases in all European Union countries (Figure 2).

In recent years, increasing causes of tularemia worldwide have been climate change, wars, natural disasters, human travels and animal movements. Global warming has resulted in an increase in the average temperature during the year, which has given rise to a very important change in the cycle of tularemia. In a study performed in Sweden, a climate scenario was developed using computer software in order to understand what could happen with tularemia in the case of global warming. In this study, an annual average $2^{\circ} \mathrm{C}$ temperature increase was predicted from 2010 to 2100 . The results of this study indicated that global warming would lead to an increase in tularemia cases in coming decades (81).

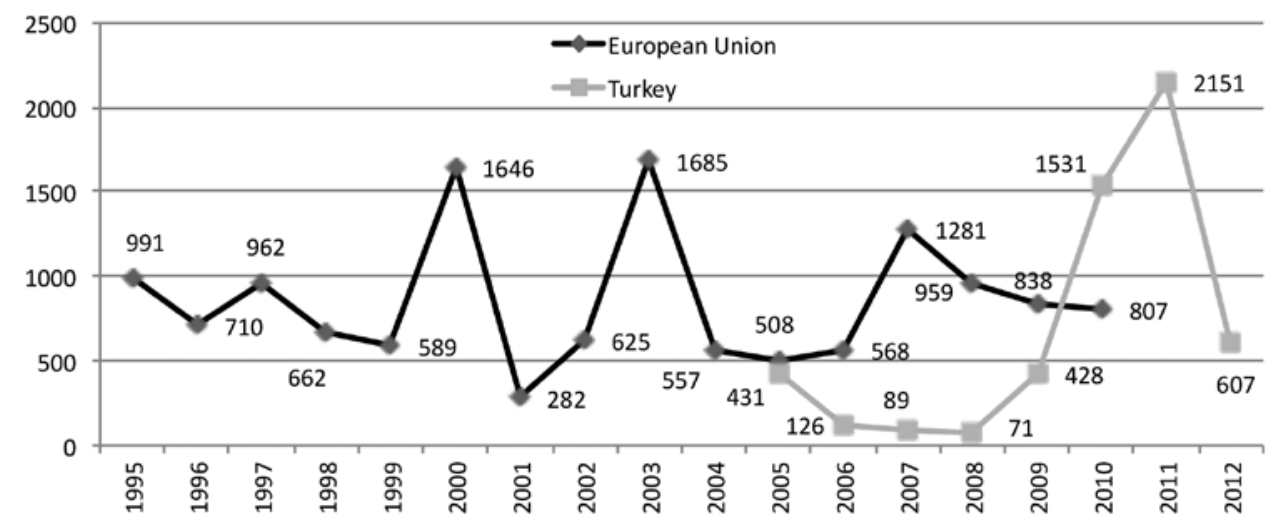

FIG. 2. Comparison of the number of the tularemia cases in European Union countries and Turkey 


\section{CONCLUSION}

Avoiding contact with vectors and reservoirs plays an important role in the control of this disease because tularemia is a zoonotic disease. Factors such as global warming, the migration of birds, and ticks on these birds cannot be controlled, but human contact with these vectors and reservoirs can be avoided. In rural areas, using protective clothes and repellents, as well as avoiding of contact with dead animals and wild animals provide protection from the disease. Hygienic conditions for food and beverages are more important than other measures in the control of the disease, especially in countries such as Turkey where the oropharyngeal form is more common. The consumption of chlorinated water and well-done meat and animal products prevents contamination via the digestive system. Early diagnosis of the disease effects both the treatment and the measures to be taken to control the disease. Performing vector surveys and investigations into the hygienic control of water resources in endemic or high risk areas will help predict probable outbreaks such that the necessary measures can be taken before the disease outbreak occurs.

\section{Ethics Committee Approval: N/A.}

\section{Informed Consent: N/A.}

Peer-review: Externally peer-reviewed.

Conflict of Interest: No conflict of interest was declared by the authors.

Financial Disclosure: The authors declared that this study has received no financial support.

\section{REFERENCES}

1. Lindquist D, Chu MC, Probert WS. Francisella and Brucella (Translated By: Çetinkaya Z.) In: Murray PR, Baron EJ, Jorgensen JH, Landry ML, Pfaller MA (Eds.). (Translation Editors: Başustaoğlu A, Kubar A, Yıldıran ŞT, Tanyüksel M.) Manual of Clinical Microbiology (Clinical Microbiology). 9.edition. Washington: ASM pres (Ankara Atlas Yayıncılık): 2009. p.815-24.

2. Ellis J, Oyston PC, Green M, Titball RW. Tularemia. Clin Microbiol Rev 2002;15:631-46. [CrossRef]

3. Pınar A. Biyolojik Silah Olarak Mikroorganizmalar. Hacettepe Tip Dergisi 2010;41:97-104.

4. Hodges L, Penn RL. Tularemia and Bioterrorism. In: Fong and Alibek (Eds.). Bioterrorism and Infectious Agents. New York: Springer Science Business Media; 2005. p.71-98.

5. Gürcan Ş. Francisella tularensis ve Türkiye'de Tularemi. Mikrobiyol Bul 2007;41:621-36.

6. Tularemi Hastalığının Kontrolü İçin Saha Rehberi. Temel Sağlık Hizmetleri Genel Müdürlüğü Zoonotik Hastalıklar Daire Başkanlığı. Ankara: Başak Matbaacılık; 2011. p.1-18.

7. Plevnelioğlu KH. Memleketimizde tularemi. Tedavi Kliniği ve Laboratuvart Dergisi 1936;6:119-35.

8. Özdemir D. Salgınların Ekonomik ve Sosyal Etkileri. In: Gürcan Ş (Ed.) Francisella tularensis ve Tularemi. İstanbul: Nobel Tip Kitabevleri; 2009. p.133-5.
9. Trevisanato SI. The "Hittite plague", an epidemic of tularemia and the first record of biological warfare. Med Hypotheses 2007;69:1371-4. [CrossRef]

10. Trevisanato SI. Did an epidemic of tularemia in Ancient Egypt affect the course of world history? Med Hypotheses 2004;63:905-10. [CrossRef]

11. Eliasson H, Broman T, Forsman M, Bäck E. Tularemia: Current Epidemiology and Disease Management. Inf Dis Clin N Am 2006;20:289-311. [CrossRef]

12. Sjöstedt A. Tularemia: history, epidemiology, pathogen physiology, and clinical manifestations. Ann N Y Acad Sci 2007;1105:1-29. [CrossRef]

13. Keim P, Johansson A, Wagner DM. Molecular Epidemiology, Evolution, and Ecology of Francisella. Ann N Y Acad Sci 2007;1105:30-66. [CrossRef]

14. Kılıç S. A General Overview of Francisella tularensis and the Epidemiology of Tularemia in Turkey. Flora 2010;15:37-58.

15. Francisella. In: Forbes BA, Sahm DF, Weissfeld AS (Eds.) Bailey\&Scott's Diagnostic Microbiology. 12th ed. Missouri: Mosby Elsevier; 2007. p.440-3.

16. Mikalsen J, Olsen AB, Tengs T, Colquhoun DJ. Francisella philomiragia subsp. noatunensis subsp. nov. , Isolated From Farmed Atlantic Cod (Godus morhua L.) Int J Syst Evol Microbiol 2007;57:1960-5. [CrossRef]

17. Ottem KF, Nylund A, Karlsbakk E, Friss- Moller A, Krossoy B, Knappskog D. New Species in the Genus Francisella sp. nov. Isolated from Cod (Gadus morhua) Arch Microbiol 2007;188:547-50. [CrossRef]

18. Colquhoun DJ, Duodu S. Francisella infections in farmed and wild aquatic organisms. Vet Res 2011;42:47. [CrossRef]

19. Huber B, Escudero R, Busse HJ, Seibold E, Scholz HC, Anda P, et al. Description of Francisella hispaniensis sp. nov., isolated from human blood, reclassification of Francisella novicida (Larson et al. 1955) Olsufiev et al. 1959 as Francisella tularensis subsp. novicida comb. nov. and emended description of the genus Francisella. Int J Syst Evol Microbiol 2010;60:1887-96. [CrossRef]

20. Qu PH, Chen SY, Scholz HG, Busse HG, Gu Q, Kämpfer P, et al. Francisella guangzhouensis sp. nov. isolated from air conditioning systems. Int J Syst Evol Microbiol 2013;63:3628-35. [CrossRef]

21. Splettstoesser W. Microbiological Characteristics and Genetic Structure of Francisella tularensis. International Symposium on Francisella Tularensis and Tularemia Abstract Book p.8-9, 19-22 June 2013, ÜrgüpNevşehir.

22. Geyik MF, Akalın H. Dünyada Tularemi. In: Gürcan \$̧ (Ed.). Francisella tularensis ve Tularemi. İstanbul: Nobel Tıp Kitabevleri; 2009. p.99-106.

23. Helvaci S, Gedikoglu S, Akalin H, Oral HB. Tularemia in Bursa, Turkey: 205 cases in ten years. Eur J Epidemiol 2000;16:271-6. [CrossRef]

24. Gürcan Ş, Eskiocak M, Varol G, Uzun C, Tatman Otkun M, Şakru N, et al. Tularemia re-emerging in European Part of Turkey after 60 years. Jpn J Infect Dis 2006;59:391-3.

25. Gürcan Ş, Otkun MT, Otkun M, Arikan OK, Ozer B. An outbreak of tularemia in Western Black Sea region of Turkey. Yonsei Med J 2004;45:17-22.

26. Özel TV. Dr. Talat Vasfi Özel'in 1937 yılı yazında Trakya tularemi tetkikat1. Türk Hij Tec Biol Der 1938;1:1-30

27. Dennis DT, Inglesby TV, Henderson DA, Bartlett JG, Ascher MS, Eitzen E, et al. Tularemia as a Biological Weapon Medical and Public Health Management. JAMA 2001;285:2763-73. [CrossRef]

28. Gürcan Ş, Varol Saraçoğlu G, Karadenizli A, Özkayın EN, Öztürk ŞZ, Çiçek C, et al. Tularemia as a result of outdoor activities for children in the countryside. Turk J Med Sci 2012;42:1044-9.

29. Gotschlich E, Berkin T. 1936 yılında Trakya'da tularemiye ait yapılan epidemiyolojik ve bakteriyolojik araştırmalar. Turk Hij Tecr Biyol Derg 1938;1:115-23.

30. Dirik K. Van Gölü havzasında Tularémie. Turk Hij Tecr Biyol Derg 1939;2:193-5.

31. Golem SB. Lüleburgaz'da yeni bir tularemi epidemisi. Turk Hij Tecr Biyol Derg 1945;5:27-40.

32. Utku IEE. Antalya'da tularemi epidemisi ve hususiyetleri. Turk Hij Tecr Biyol Derg 1954;14:288-93.

33. Erbay A, Dokuzoğuz B, Baykam N, Güvener E, Diker S, Yıldırmak T. Ankara yöresinde tularemi. İnfeksiyon Dergisi 2000;14:453-8.

34. Ozdemir D, Sencan I, Annakkaya AN, Karadenizli A, Guclu E, Sert E, et al. Comparison of the 2000 and 2005 outbreaks of tularemia in the Duzce region of Turkey. Jpn J Infect Dis 2007;60:51-2. 
35. Leblebicioğlu H, Esen S, Turan D, Tanyeri Y, Karadenizli A, Ziyagil F, et al. Outbreak of tularemia: a case-control study and environmental investigation in Turkey. Int J Infect Dis 2008;12:265-9. [CrossRef]

36. Celebi G, Baruonu F, Ayoglu F, Cinar F, Karadenizli A, Uğur MB, et al. Tularemia, a reemerging disease in northwest Turkey: epidemiological investigation and evaluation of treatment responses. Jpn J Infect Dis 2006;59:229-34.

37. Sahin M, Atabay HI, Bicakcı Z, Unver A, Otlu S. Outbreaks of tularemia in Turkey. Kobe J Med Sci 2007;53:37-42.

38. Meric M, Willke A, Finke EJ, Grunow R, Sayan M, Erdogan S, et al. Evaluation of clinical, laboratory, and therapeutic features of 145 tularemia cases: the role of quinolones in oropharyngeal tularemia. APMIS 2008;116:66-73. [CrossRef]

39. Meriç M, Sayan M, Willke A, Gedikoğlu S. Su kaynaklı küçük bir tularemi salgını. Mikrobiyol Bul 2008;42:49-59.

40. Acicbe Ö, Aydın H, Doğancı L. Havza/Samsun Bölgesi'nde tularemi endemisi: İzlenen olguların retrospektif yorumu. İnfeksiyon Dergisi 2007;21:55-8.

41. Meriç M, Sayan M, Dündar D, Willke A. Tularaemia outbreaks in Sakarya, Turkey: case-control and environmental studies. Singapore Med $J$ 2010;51:655-9.

42. Karabay O, Gürcan Ş, Karadenizli A, Vahaboglu H. Second tularemia outbreak within 5 years in same village of Bolu, Turkey. The First International Congress of Central Asia Infectious Diseases. Program and Abstracts Book, p.80. October 30- November 2, 2006. Bishkek, Kyrgy Republic.

43. Barut S, Cetin I. A tularemia outbreak in an extended family in Tokat Province, Turkey: observing the attack rate of tularemia. Int J Infect Dis 2009;13:745-8. [CrossRef]

44. Gönena İ. A small outbreak of tularemia in a rural area. Turk J Med Sci 2013;43:75-8.

45. Engin A, Altuntaş EE, Cankorkmaz L, Kaya A, Elaldı N, Şimşek $\mathrm{H}$, et al. Sivas İlinde Saptanan İlk Tularemi Salgını: 29 Olgunun Değerlendirilmesi. Klimik Dergisi 2011;24:17-23. [CrossRef]

46. Tatman Otkun M, Akçalı A, Karadenizli A, Ozbey N, Gazel D, Sener A, et al. Çanakkale'de Hızla Önlenen Bir Tularemi Salgınının Epidemiyolojik Olarak Değerlendirilmesi. Mikrobiyol Bul 2011;45:48-57.

47. Ulu Kılıç A, Kılıç S, Sencan I, Ciçek Şentürk G, Gürbüz Y, Tütüncü EE, et al. 2011. İç Anadolu Bölgesinde Francisella tularensis alt tür halorctica'ya Bağlı Su Kaynaklı Bir Tularemi Salgını. Mikrobiyol Bul 2011;45:234-47.

48. Dikici N, Ural O, Sümer S, Öztürk K, Albayrak Yiğit O, Katlanır E, et al. Tularemia in Konya region, Turkey. Mikrobiyol Bul 2012;46:225-35.

49. Ulu-Kilic A, Gulen G, Sezen F, Kilic S, Sencan I. Tularemia in Central Anatolia. Infection 2013;41:391-9. [CrossRef]

50. Şahin M. Francisella tularensis'in Vektörleri ve Doğal Rezervuarları. In: Gürcan Ş (Ed.) Francisella tularensis ve Tularemi. İstanbul: Nobel Tip Kitabevleri; 2009. p.139-60.

51. Telford SR, Goethert HK. Toward an understanding of the perpetuation of the agent of tularemia. Front Microbiol 2011;150:1-7.

52. Chen W, Shen H, Webb A, KuoLee R, Conlan JW. Tularemia in BALB/c and C57BL/6 mice vaccinated with Francisella tularensis LVS and challenged intradermally, or by aerosol with virulent isolates of the pathogen: protection varies depending on pathogenvirulence, route of exposure, and host genetic background. Vaccine 2003;21:3690-700. [CrossRef]

53. Wobeser G, Campbell GD, Dallaire A, McBurney S. Tularemia, plague, yersiniosis and Tyzzer's disease in wild rodents and lagomorphs in Canada: A review. Can Vet J 2009;50:1251-6.

54. Christova I, Gladnishka T. Prevalence of Infection With Francisella tularensis, Borrelia burgdorferi sensu lato and Anaplasma phagocytophilum in Rodents From an Endemic Focus of Tularemia In Bulgaria. Ann Agric Environ Med 2005;12:149-52.

55. Reintjes R, Dedushaj I, Gjini A, Jorgensen TR, Cotter B, Lieftucht A, et al. Tularemia outbreak investigation in Kosovo: case control and environmental studies. Emerg Infect Dis 2002;8:69-73. [CrossRef]

56. Otlu S. Hayvanlarda Tularemi Araştırmaları ve Dünyada Durum. In: Gürcan Ş (Ed.) Francisella tularensis ve Tularemi. İstanbul: Nobel Tıp Kitabevleri; 2009. p.161-8.

57. Kaygusuz S, Arikan O, Azkur K, Simsek H, Gazyagci S, Muluk N, et al. Epidemia of tularemia in Central Anatolia. Journal of Animal and Veterinary Advances 2010;9:1702-6. [CrossRef]
58. Kılıçturgay K, Gökırmak F, Gedikoğlu S, Helvacı S, Töre O, Tolunay Ş. Bursa'da tularemi epidemisi. İnfeksiyon Dergisi 1989;3:149-56.

59. Özsan K, Fazh A, Aktan M, Beyoğlu K. Brucellosis, tularemia and borreliosis isolated from wild animals captured in Ankara, Konya, Urfa and Nevsehir provinces in Turkey. Mikrobiyol Bul 1976;10:413-21.

60. Ünal-Yılmaz G, Gürcan Ş, Özkan B, Karadenizli A. Investigation of Francisella tularensis by using culture, serology and molecular methods in rats of Thrace Region, Turkey. International Symposium on Francisella tularensis and Tularemia. Abstract Book, p.51-52. 19-22 June 2013, Ürgüp, Nevşehir.

61. Abd H, Johansson T, Golovliov I, Sandström G, Forsman M. Survival and growth of Francisella tularensis in Acanthamoeba castellanii. Appl Environ Microbiol 2003;69:600-6. [CrossRef]

62. Petersen JM, Schriefer ME. Tularemia: emergence/re-emergence. Vet Res 2005;36:455-67. [CrossRef]

63. Cbelli VJ, Hodapp FA, Ferguson EW, et al. Tularemia: Potential for transmission by birds. Zoonoses Res 1964;3:99-124.

64. Padeshki PI, Ivanov IN, Popov B, Kantardjiev TV. The role of birds in dissemination of Francisella tularensis: first direct molecular evidence for birdto-human transmission. Epidemiol Infect 2010;138:376-9. [CrossRef]

65. Petersen JM, Mead PS, Schriefer ME. Francisella tularensis: an arthropod-borne pathogen. Vet Res 2009;40:1-9. [CrossRef]

66. Olin G. The occurence and mode of transmission of tularemia in Sweden. Acta Pathol 1941;29:220-47.

67. Yeşilyurt M, Kilıç S, Çağaşar Ö, Çelebi B, Gül S. Yozgat İlinde Kene Kaynaklı İki Tularemi Olgusu. Mikrobiyol Bul 2011;45:746-54.

68. Şencan İ, Şahin İ, Kaya D, Öksüz Ş, Özdemir D, Karabay O. An outbreak of oropharyngeal tularemia with cervical adenopathy predominantly in the left side. Yonsei Med J 2009;50:50-4. [CrossRef]

69. Miller AA. Tularemia and new data on its epidemiology. Sov Vrach Gaz 1935;39:187-98

70. Şahin İ. Tulareminin Genel Epidemiyolojik Özellikleri. In: Gürcan \$̧ (Ed.) Francisella tularensis ve Tularemi. İstanbul: Nobel Tip Kitabevleri; 2009. p.89-93.

71. Grunow R, Kalaveshi A, Kühn A, Mulliqi-Osmani G, Ramadani N Surveillance of tularaemia in Kosovo, 2001 to 2010. Euro Surveill 2012;17:20217.

72. Gürcan Ş. Francisella tularensis ve tularemi hastalığının epidemiyolojisi. XXXV. Türk Mikrobiyoloji Kongresi Özet Kitabı s.149-50. 3-7 November 2012, Kuşadası-Aydın.

73. Jackson J, McGregor A, Cooley L, Ng J, Brown M, Ong CW, et al. Francisella tularensis subspecies holarctica, Tasmania, Australia, 2011. Emerg Infect Dis 2012;18:1484-6. [CrossRef]

74. Whipp MJ, Davis JM, Lum G, et al. Characterization of a novicida-like subspecies of Francisella tularensis isolated in Australia. J Med Microbiol 2003;52:839-42. [CrossRef]

75. Gedikoğlu S, Göral G, Helvacı S. Bursa'daki tularemi epidemisinin özellikleri. İnfeksiyon Dergisi 1990;4:9-15.

76. Willke-Topçu A. Bursa ve Kocaeli Yöresi Salgınları. In: Gürcan, Ş. (Ed.) Francisella tularensis ve Tularemi. İstanbul: Nobel Tip Kitabevleri; 2009. p.115-6.

77. Gedikoğlu S. 2004. Bakteriyel Zoonozlar: Tularemi. XXXI. Türk Mikrobiyoloji Kongresi. XXXI.Türk Mikrobiyoloji Kongresi Kongre Kitabı, p.123-12419-23 September 2013, Kuşadası, Aydın.

78. Turhan V, Ardıç N, Şahinoğlu L, Beşirbellioğlu BA, Gedikoğlu S. A General View to Tularemia Cases in Turkey: On to a Pure Oropharyngeal Type Outbreak. AJCI 2007;1:71-7.

79. Karabay O, Kılıç S, Gürcan Ş, Pelitli T, Karadenizli A, Bozkurt H, et al. Cervical lymphadenitis: tuberculosis or tularaemia? Clin Microbiol Infect 2013;19:113-7. [CrossRef]

80. Torunoğlu MA. Tularemi Epidemiyolojisi Tularemi Vakalarının Coğrafik Dağılımı. 4. Türkiye EKMUD Kongresi Kongre Kitabı p.1003. 9-12 May 2012, Pendik-İstanbul. Int J Infect Dis 2009;13:745-8.

81. Rydén P, Sjöstedt A, Johansson A. Effects of climate change on tularaemia disease activity in Sweden. Glob Health Action 2009;2:1-7. 